ОСОБЛИВОСТІ РОЗВИТКУ

СВІТОВОГО ГОСПОДАРСТВА ТА МЕВ

УДК $339.9+331.556 .4$

\title{
KEY TRENDS IN INTERNATIONAL REGULATION OF INTELLECTUAL MIGRATION
}

\author{
КЛЮЧОВІ ТРЕНДИ МІЖНАРОДНОГО РЕГУЛЮВАННЯ \\ ІНТЕЛЕКТУАЛЬНОЇ МІГРАЦЇ̈
}

\section{КЛЮЧЕВЫЕ ТРЕНДЫ МЕЖДУНАРОДНОГО РЕГУЛИРОВАНИЯ ИНТЕЛЛЕКТУАЛЬНОЙ МИГРАЦИИ}

\begin{abstract}
Stakanov R.
Dr of Sc. (Economics), Professor of the Department of World Economy and International Economic Relations of Taras Shevchenko National University of Kyiv. Email: roman.stakanov@gmail.com

\section{Savchuk A.}

PhD student of the Department of World Economy and International Economic Relations of Taras Shevchenko National University of Kyiv. Email: anneukhova@gmail.com

\section{Стаканов Р.Д.}

Доктор економічних наук, доцент, професор кафедри світового господарства і міжнародних економічних відносин Інституту міжнародних відносин Київського національного університету імені Тараса Шевченка. Еmail: roman.stakanov@gmail.com
\end{abstract}

\section{Савчук А.B.}

Аспірант кафедри світового господарства іміжнародних економічних відносин Інституту міжнародних відносин Київського національного університету імені Тараса Шевченка. E-mail: anneukhova@gmail.com

\section{Стаканов Р.Д.}

Доктор экономических наук, доцент, профессор кафедры мирового хозяйства и международных экономических отношений Института международных отношений Киевского национального университета имени Тараса Шевченко. E-mail: roman.stakanov@gmail.com

\section{Савчук А.B.}

Аспирант кафедры мирового хозяйства и международных экономических отношений Института международных отношений Киевского национального университета имени Тараса Шевченко. Е-таil: anneukhova@gmail.com

Abstract. The main purpose of the article is to analyze the regulation of intellectual migration and to determine the levels and mechanism of regulation, to study the features of international migration of highly skilled workers. The advantages and disadvantages for donor and recipient countries of intellectual migrants are considered. The main directions and centers of attraction of migrants in the world are analyzed.

Key words: intellectual migrant, international migration, regulation of international migration, "brain drain", global labour market

Анотація. Головною метою статті є аналіз регулювання інтелектуальної міграціі та визначення рівнів та механізму регулювання, дослідження особливостей міжнародної міграції висококваліфікованих працівників. Розглянуто переваги та недоліки для країндонорів та країн-рещипієнтів інтелектуальних мігрантів. Проаналізовано основні напрями 
та иеетти тяжіння мігрантів у світі.

Ключові слова: інтелектуальний мігрант, міжнародна міграчія, регулювання міжнародної міграції, "brain drain", глобальний ринок праці

Аннотация. Главной ичелью статьи является анализ регулирования интеллектуальной миграции и определения уровней и механизма регулирования, исследование особенностей международной миграчии высококвалифицированных работников. Рассмотрень преимущества и недостатки для стран-доноров и стран-рециипентов интеллектуальных мигрантов. Проанализированы основные направления и иентры притяжения мигрантов в мире.

Ключевые слова: интеллектуальный мигрант, международная миграция, регулирование международной мигращии, "brain drain", глобальный рынок труда.

Introduction. The globalization of the world labor market causes a general equalization of average wages between countries, while increasing the income gap between different categories of workers, whereby this trend is typical for both the developed countries, and developing countries, and the global economy as a whole.

The growing income gap is primarily an increase in the differentiation of factor incomes - labor and capital, in favor of the latter. Highly skilled workers in today's global labor market are, first of all, owners of capital (both financial - necessary to obtain the appropriate level of knowledge and and intellectual - the necessary abilities and talents, which also have their own financial expression), than the classical workforce. Recently, global competition for skilled labour has intensified, which was due, in particular, to the reduction of skilled labour in many developed countries, as well as the general population aging in particular, in post-industrial countries. Recently, intensified global competition for skilled labor, which was due, in particular, a reduction in skilled labor in many developed countries, and the general aging of the population and the workforce in most postindustrial countries. That is one of the determining factors for these countries to implement a stimulating migration policy for highly skilled workers. Still, the regulation is further one of the most difficult problems of labour migration, which not all states have managed to solve. The experience in migration management shows that an individual state cannot achieve results without interaction with others.

Migrants are in two legal systems: the country of their citizenship and the country of residence. The regulation of norms and procedures of departure of people from one country and entry into another is the sphere of international relations. The need to manage international labour migration is growing under the influence of globalization and intensified by the problems both in the countries of origin of migrants, and in the host countries, as well as in transit countries, and in the world community as a whole.

The purpose of the study is to analyze the regulation of migration of highly qualified personnel, to determine the levels of regulation of international migration, to identify the mechanism of regulation.

Recent literature review. The study and analysis of the regulation of international migration of highly skilled workers has received a great deal of attention from foreign scholars, including Bailey A., Mulder C. H. [Bailey, Mulder, 2017], Czaika M., Parsons C. R. [Czaika, Parsons, 2016], Nathan M. [Nathan, 2013], Weinar A., Klekowski von Koppenfels A. [Weinar, Klekowski von Koppenfels, 2020]. Important contributions to the study of international intellectual migration have been made by the list of Ukrainian scholars, such as Erfan Y. [Erfan, 2018], Zaychuk V. [Zaychuk, 2009], Mayev A. [Mayev, 2016], Davydyuk L. [Davydyuk, 2019]. At the same time, there are relatively few publications in the national literature, which cover the theoretical and methodological foundations of international migration' regulation, namely the levels of regulation of international migration (supranational level, level of international regional associations, state level, informal ways of regulation). The methodological basis of the study was 
documents, analytical data and statistics from the United Nations (UN), the International Organization for Migration (IOM), the International Labor Organization (ILO) and others.

The main results of the research. Intellectual migration as a contradictory and ambiguous phenomenon requires specific measures for regulation, it should be carried out through international legal regulation of migration processes taking into account the global interests of the world community, the objective capabilities of individual states and features of population development in modern conditions [Erfan, 2018: 10]. The peculiarities of the current stage of migration processes are the strengthening of the regulation of the international movement of labor by all actors in migration relations. A multilevel system of regulation of international labor migration, including highly skilled workers, has been formed, including international, supranational, national, as well as regulation at the level of domestic regions and informal methods of regulation (Fig. 1.)

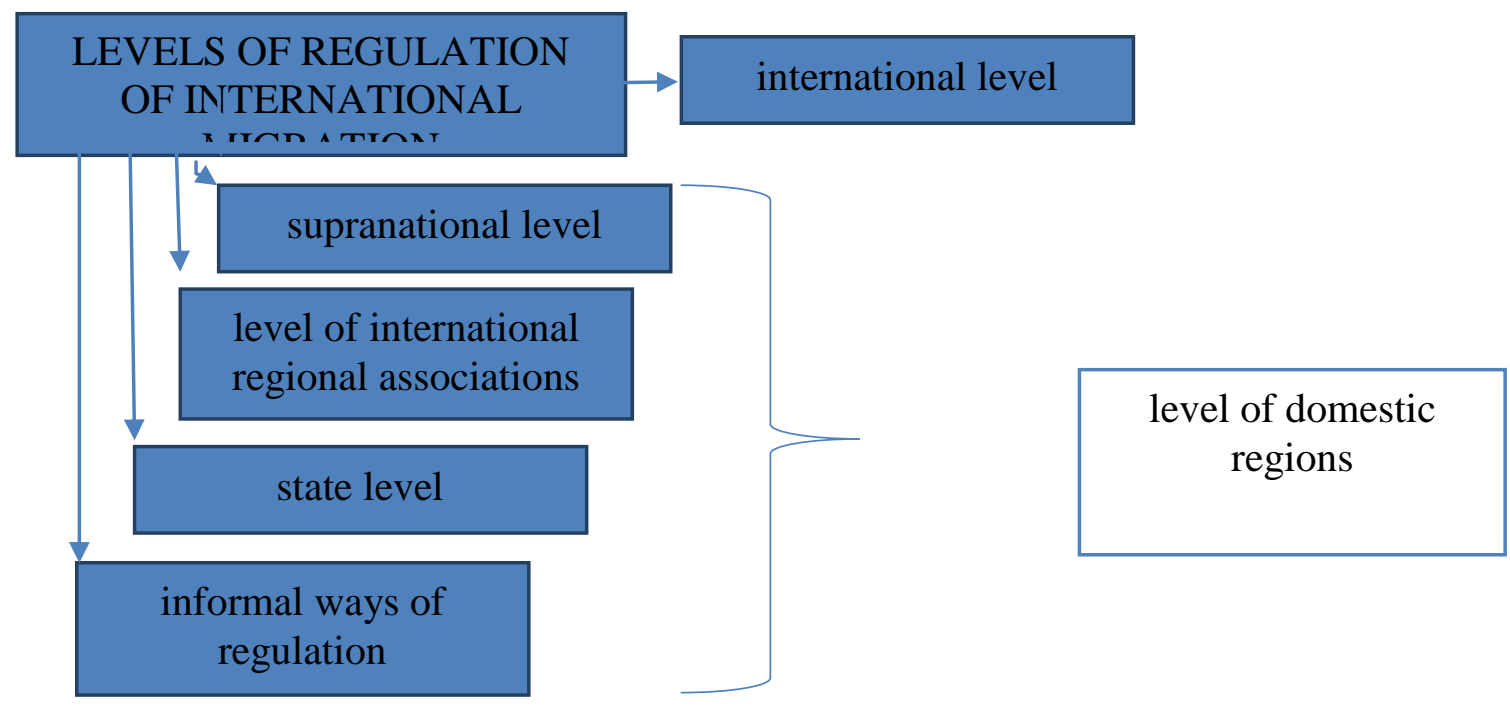

Fig. 1. Multilevel system of regulation of international labor migration.

In the XIX century, the processes of international labor migration began to be regulated by agreements on a bilateral basis: between labor-exporting country and labor-importing country. As international labor migration increases and more countries become involved, regulation based on bilateral and multilateral interstate agreements is expanding. The interconnectedness of states in the context of globalization has reached such a degree that it is very difficult not to take into account the norms and principles established by international organizations. The state may not accede (or not ratify for a long time) certain documents developed by international organizations, but this, firstly, worsens the country's competitive position in the world labor market, and, secondly, causes a certain negative reaction from the world community.

At the present stage of development of the world economy, states have a duty to develop the social orientation of immigration policy, to adhere to the principles enshrined in the Univerrsal Declaration of Human Rights, adopted in 1948 and other documents of international organizations.

At the international level, the migration and labor of migrants are regulated by a number of international organizations. The leading role in regulating the processes of international labor migration belongs to the International Labor Organization (ILO). The ILO was established on April 11, 1919 under the League of Nations in accordance with the Treaty of Versailles. Its purpose was to promote the principles of social justice, internationally recognized human rights in the field of labor. The ILO was the first intergovernmental organization to create conventions and recommendations on labor law, promote socio-economic progress, increase welfare and improve working conditions, and protect human rights. In 1949, Convention 97 on Migrant Workers was adopted [ILO, 1949]. The provisions of this Convention remain relevant to this day. The document 
applies to immigrants legally staying in the country and provides for the right of migrant workers to permanent residence in the host country after a certain period of work. In 1955, the ILO adopted another important document, Recommendation 100 on the Protection of Migrant Workers in Developing Countries [ILO, 1955]. This document aims to regulate migration in the interests of social and economic development of developing countries, limiting the undesirable loss of labor resources for these countries. Among the proposed measures - the adoption of special programs of economic development in the countries of emigration, the creation of new jobs.

Each ILO member country must: ensure the application of the principle of equal opportunities for migrant workers and members of their families to nationals of their country, examine complaints of non-compliance with this principle (in case of violations by entrepreneurs or other persons or organizations responsible for their implementation, apply administrative, civil and criminal penalties); ensure compliance of national laws and rules of international norms with the rights of migrants; promote the reunification of families as soon as possible; promote the coordination of the activities of social services on its territory with the social services of other countries and be responsible for their work; consult on emerging problems of migrants.

The activities of the International Organization for Migration (IOM) are aimed at streamlining and humanizing measures to regulate migration, developing international cooperation in the field of migration, and providing assistance in finding practical solutions to problems. Founded in 1951, IOM is a leading intergovernmental institution in the field of migration, working with governmental, intergovernmental and non-governmental organizations to ensure the orderly movement of refugees and others in need of assistance in international migration. It should be noted that the activities of the International Organization for Migration are aimed at protecting the rights of all categories of migrants.

The socially-oriented approach to the regulation of migration relations has been enshrined in the norms of international law, to which most states give priority to the norms of national law. International law contains three main concepts that characterize the protection of migrants:

1 equal treatment of legal migrant workers and citizens of the country;

2 basic universal human rights apply to all people, including migrants;

3 a wide range of international labor standards that provide protection in the treatment of workers, the creation of working conditions (including health and safety, maximum working hours, non-discrimination, maternity leave, etc.) applicable to all workers.

The objective need to adapt to the new attitude to migrants forces all countries involved in international labor migration to reconsider their approaches to its assessment, to take into account in their migration policy norms and principles of international organizations, to understand the inevitability of cooperation with migration partner countries. In real practice, there are two approaches to interstate cooperation. The first approach is manifested in the active position of the states developing cooperation on the basis of balance of national interests, development of the corresponding programs and creation of institutional structures; the second approach is to limit migration cooperation.

Within integration associations, migration cooperation is even closer, and the migration regime is becoming liberal. Thus, the legal basis for improving the management of migration processes in the CIS is a multilateral international document - European Convention on the Legal Status of Migrant Workers and Members of Their Families, signed on November 14, 2008 [IOM, 2008]. The purpose of the Convention is to create conditions for equal treatment of migrant workers, members of their families and nationals of the host country, as well as favorable conditions for the movement of labor across the territories of the participating States.

In integration associations, the liberalization of migration regimes at the regional level often contradicts the national interests of an individual country. For example, the attitude towards migrant workers in Greece with an unemployment rate of $15.8 \%$ and $34.2 \%$ among young people (December 2020) [Take-profit, 2021a] and Germany, where unemployment was $4.6 \%$ and 6.6\%, respectively, cannot be the same (January 2021) [Take-profit, 2021b]. 
The state level of regulation is aimed at ensuring the priority use of national labor resources, taking into account the situation on the labor market, as well as to ensure control over the attraction and use of foreign labor. The government of each country determines the directions and goals of migration policy. However, the world community has recognized a reasonable and necessary condition for states in developing a set of measures to regulate labor migration, to adhere to certain legal norms and standards enshrined in the documents of international organizations. States, by ratifying international conventions governing the process of labor migration, recognize the priority of international law over national law, which is important both for the country itself in terms of its integration into the world community, and for migrants whose rights abroad are significantly expanded and need protection. At the same time, each state in the implementation of international principles in regulating the processes of international labor migration on its territory can not ignore existing trends and prospects for socio-economic and demographic development, determined by the state strategy.

Reform of migration policy in developed countries went in two directions: strengthening mechanisms for the selection of migrant workers in favor of highly qualified professionals and limiting the entry of low-skilled migrants. For example, Council Directive 2009/50 / EU of 25 May 2009 was aimed at attracting highly qualified specialists to the European Union in order to create favorable conditions for the relocation, residence and employment of highly qualified labor in the EU [Zaychuk, 2009: 42].

As world practice shows, all states seek to develop mechanisms for regulating external labor immigration that could ensure a balance of interests: the state - society - entrepreneurs - citizens migrants, the interests of the country and other states on the basis of international norms and principles adopted by international organizations (Fig. 2.). But all countries apply the existing legislation depending on fluctuations in the labor market, specialty and qualifications of the migrant, the country of origin.

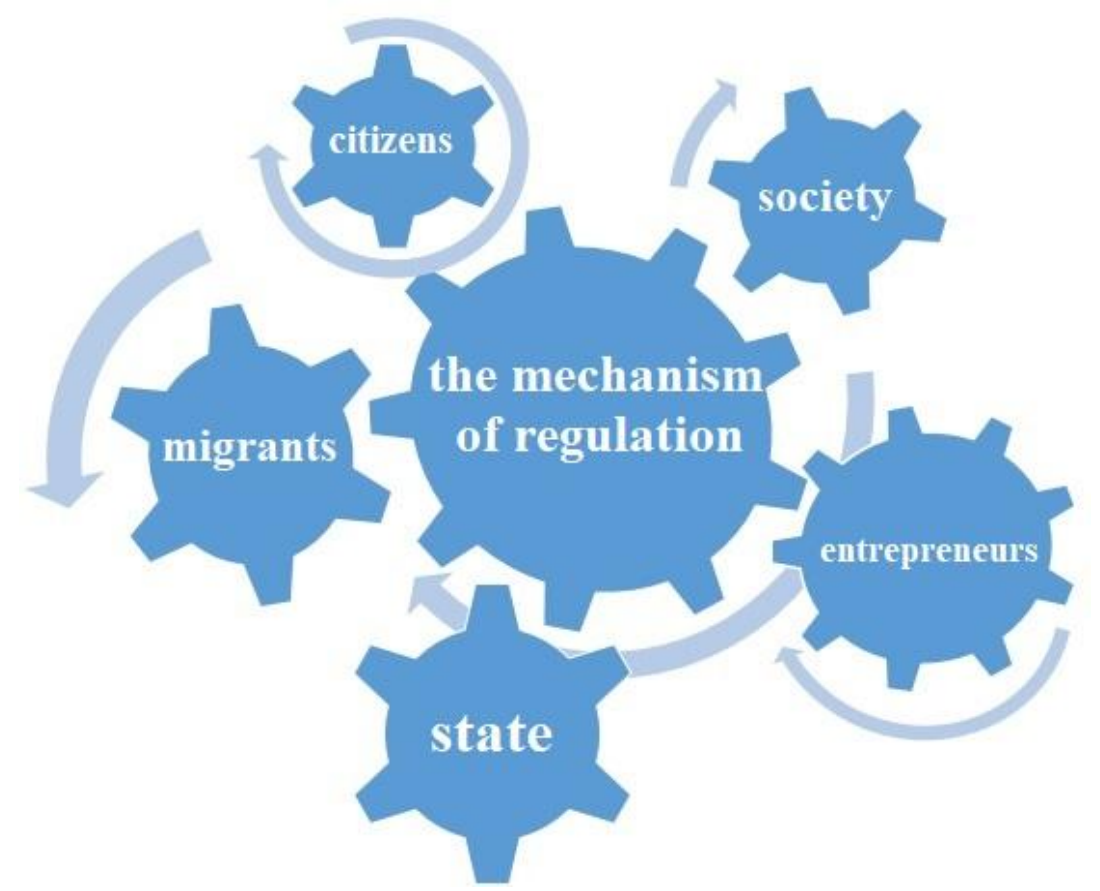

Fig. 2. Balance of interests for successful regulation of labor migration

Regulating international labor migration at the state level, each country is forced to resolve a number of conceptual contradictions, such as the need to ensure the priority use of national labor resources in accordance with their demographic and economic interests. Regulation of labor immigration processes at the national level is determined by both national economic interests and the need to preserve national culture, identity and traditions. Based on these considerations, in some developed countries the regulation of migration relations is based in part on the concept of "cooperation instead of migration". For example, France adopted the Chevenement law in 1998, the 
main idea was to help other countries train the necessary specialists and researchers for a limited period of stay in France so they could then return home and promote its economic development, as well as close relations with France [Mayev, 2016: 94].

The organization of labor migration and its scale in all countries has always been determined by the historical conditions of their development. The direction and nature of changes in immigration policy depend on the country's immigration history. Australia, Canada, New Zealand and the United States are among the leading countries of traditional immigration. Each country has established its own system of migration management, which is based on the observance of economic interests and international humanitarian obligations. In these countries there is an active selection of qualified personnel of interest to the host country.

The motivation of the policy to encourage the inflows of highly qualified specialists from abroad, which is carried out by industrialized countries, is quite clear. The most interesting thing is that the processes of intellectual migration are not always negatively perceived by the authorities of the countries. Often the authorities of donor countries suffering from the "brain drain" support the existing migration trends. First, skilled migrants, like other participants in cross-border movements, invariably send large sums of money to relatives. Secondly, in many developing countries due to the departure of qualified personnel, the unemployment rate among the educated part of society is reduced, and thirdly, when preparing to leave the world's poorest countries, people incur significant costs for education and thus contribute to raising the level of education in their country.

However, most states still try to counteract the outflow of their specialists, rather than encourage "brain drain" or enjoy its benefits. Some countries legally prohibit the departure of certain categories of professionals - for example, doctors and teachers [Davydyuk, 2019: 4]. However, this does not solve the problem.

Departure-oriented professionals use various opportunities to overcome official prohibitions, for example, by concealing the availability of appropriate qualifications, entering into fictitious marriages or obtaining certificates of non-existent diseases. More promising, compared to purely prohibitive measures, is the approach adopted in the middle of the last decade by EU countries. Concerned about the scale of the "brain drain" to the United States and Great Britain, creating not only a hypothetical but also a practical problem of preserving the national scientific elite, EU countries seek to systematically increase spending on science. This helps to ensure the employment of the best graduates of local universities and to develop programs to support the repatriation of intellectual migrants.

With regard to measures to attract foreign professionals, which are done to stimulate the influx of intellectual migrants, in addition to the development of a network of recruitment agencies, there are other methods. In most cases, they focus on the selective selection of talented foreign youth who are studying in universities and speak the language of the host country, which is usually English.

The United States, Australia, New Zealand, Canada, France and the United Kingdom are easing visa requirements for foreign applicants, offering preferential tuition schemes for the best students, and facilitating the process of obtaining citizenship by graduates of higher education institutions. However, today such an approach, reminiscent of conventional market dumping, is no longer so popular. The situation, which existed five or seven years ago, is changing and is limited not only by budgetary problems, but also by growing public sentiment directed against the excessive influx of potential competitors into the skilled labor markets.

Among the official mechanisms for stimulating intellectual immigration is the experience of a number of countries, including the United Kingdom, France, Germany and Japan, in providing special visas for highly qualified professionals that allow them to work under long-term contracts. The number of such special visas issued, for example, by Japan, has reached several hundred thousand in the last ten years.

Conclusions. Thus, the main postulate of regulating migration relations at the international level is the requirement to provide migrants with the rights they should have as individuals. 
International norms and principles developed by international organizations affect the content of national law governing migration processes that take place at the national and regional levels. The strengthening of the role of regulating international labor migration is due to new conceptual approaches based on the principles and provisions adopted by international organizations and enshrined in the UN General Assembly the Universal Declaration of Human Rights, the Constitution of the International Organization for Migration, conventions and recommendations of the International Labor Organization. Effective state regulation of international labor migration is ensured by participation in bilateral, multilateral, regional migration agreements aimed at ensuring the interests of attracting foreign labor in accordance with the needs of the labor market in terms of number and structure of flows, as well as respecting the rights of migrant workers. Therefore, intellectual migration is a complex phenomenon that ambiguously affects the socio-economic development of donor and recipient countries.

\section{References}

1 Bailey A, Mulder C. H. (2017) 'Highly skilled migration between the Global North and South: gender, life courses and institutions', Journal of Ethnic and Migration Studies, 43:16, 2689-

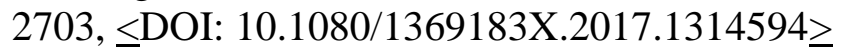

2 Czaika M., Parsons C. R. (2016) 'The Gravity of High-Skilled Migration Policies', KNOMAD WORKING PAPER 13 <https://www.knomad.org/sites/default/files/201704/KNOMAD\%20Working\%20Paper\%2013\%20HighSkilledMigration_0.pdf >

3 Davydyuk L. (2019) 'Intelektualna mihratsiia trudovykh resursiv v umovakh hlobalizatsii' [Intellectual migration of labor resources in the context of globalization], Effective economy 11. Dnipro, <http://www.economy.nayka.com.ua/pdf/11_2019/71.pdf>

4 Erfan Y.A. (2018) 'Osoblyvosti mizhnarodnoi mihratsii vysokokvalifikovanykh pratsivnykiv' [Features of international migration of highly skilled workers], Naukovyi visnyk Uzhhorodskoho natsionalnoho universytetu, 18 (II): 10 , <http://lib.znau.edu.ua/jirbis2/images/phocagallery/2017/Pryklady_DSTU_8302_2015.pdf>

5 International Labor Organization (1949) 'Migration for Employment Convention (Revised), 1949

(No. 97)', <https://www.ilo.org/dyn/normlex/en/f?p=NORMLEXPUB:12100:0::NO::p12100_instrument_id:3 $12242 />$

6 International Labor Organization (1955) 'R100 - Protection of Migrant Workers (Underdeveloped Countries) Recommendation, $1955 \quad$ (No. 100)', $<$ https://www.ilo.org/dyn/normlex/en/f?p=NORMLEXPUB:12100:0::NO::p12100_instrument_id:3 $12242 />$

7 International Organization for Migration (2008) 'European Convention on the Legal Status of Migrant Workers and Members of Their Families', < https://www.iom.org.ua/en/legislation/migration-related-legislation/workers-and-members-of-theirfamilies.html>

8 Mayev A.P. (2016) 'Kontseptualni zasady rozbudovy instytutu rehionalnoho upravlinnia v suchasnii Ukraini: yevropeiskyi ta vitchyznianyi dosvid' [Conceptual principles of development of the institute of regional management in modern Ukraine: European and domestic experience], Odessa Regional Institute for Public Administration of the National Academy for Public Administration under the President of Ukraine. Odessa.

9 Nathan M. (2013) 'The Wider Economic Impacts of High-Skilled Migrants: A Survey of the Literature' IZA Discussion Papers, No. 7653, Institute for the Study of Labor (IZA), Bonn < https://www.econstor.eu/bitstream/10419/89999/1/dp7653.pdf >

10 Take-profit (2021a). 'Unemployment rate and employment data in Greece', <https://takeprofit.org/en/statistics/unemployment-rate/greece/>

11 Take-profit (2021b). 'Unemployment rate and employment data in Germany', < https://takeprofit.org/en/statistics/unemployment-rate/germany/> 
12 Weinar A., Klekowski von Koppenfels A. (2020) 'The State and the Highly Skilled Immigrant', Highly-Skilled Migration: Between Settlement and Mobility. IMISCOE Research Series. Springer, Cham. <https://doi.org/10.1007/978-3-030-42204-2_3>

13 Zaychuk V.O. (2009) 'Referatyvnyi ohliad yevropeiskoho prava' [Abstract review of European law], Legislation Institute of The Verkhovna Rada of Ukraine 14. Kyiv, < http://instzak.rada.gov.ua/uploads/documents/31600.pdf > 